\title{
Parkinson disease of ranking lawyer and legislator SJV Chelvanayakam: a hypothesis
}

(Index words: Biography, Chelvanayakam, neurotoxin, organotin, Parkinsonism)

\begin{abstract}
SJV Chelvanayakam (1898-1977), a ranking civil lawyer and legislator, was probably the well known Parkinson disease victim in the 20th century Sri Lanka. He was born in Ipoh, Malaya, where his father had moved in the last decade of the 19th century for professional advancement. Ipoh was then an attractive location for migrants from China and the Indian subcontinent since it was in the Kinta valley-touted then, as the world's richest single tin field. Chelvanayakam was brought to Jaffna peninsula when he was aged four (in 1902 or 1903) by his mother, who returned to her native Tellipalai town partly due to indifferent health during her stay in Kinta region. In this communication, I present a hypothesis that organotin exposure as a foetus or during infancy at his place of birth is likely to have been a contributing factor to Chelvanayakam's Parkinsonism. It seems to fit the available circumstantial evidence.
\end{abstract}

\section{Introduction}

Since I first saw him as a schoolboy in 1963, I had long been interested in the sickness of Samuel James Velupillai Chelvanayakam (1898-1977; hereafter mentioned by his shortened appellation, Chelva), a well known public figure for nearly 50 years in the 20th century Sri Lanka. He was a leading civil lawyer in the British colonial era for two decades (from 1927 to 1946), as recounted by N. Sinnetamby, Shiva Pasupati and Victor Tennekoon [1]. He then plunged into politics and represented the Kankesanthurai constituency in the parliament of Ceylon (Sri Lanka) for a lengthy spell, from 1947 to 1952,1956 to 1972 and 1975 to 1977 [2]. On Chelva's public stature in Sri Lanka, it has been noted: "From 1958 to 1977 he was the undisputed leader of the Sri Lankan Tamils. This was particularly remarkable because from the early 1950s he suffered from Parkinson's disease that debilitated him and impaired his speech" [3].

To the best of my knowledge, I have not come across a published report on the cause(s) of Chelva's Parkinsonism. Even Jeyaratnam Wilson, his son-in-law, has skirted this issue in his published biography on Chelva [4], though he provides a few essential facts. They include the following: (a) Before the 1956 general election, Chelva "became increasingly ill with Parkinson's disease, [and] expressed his desire to retire from politics....". (b) In 1961, Chelva underwent surgery in Edinburgh to relieve the stress from Parkinson disease at the hands of a neurosurgeon, Francis John Gillingham and the operation "proved successful". (c) Though he was able to sleep better as a result of surgery, a few years later, by 1965 , "the beneficial effects [of surgery] had begun to wear off, making the earlier symptoms reappear...". Though Chelva lived for another 12 years, according to his biographer, "he suffered from more frequent falls late in his life and the resulting injuries caused his condition to worsen."[4]. From 1965 to 1976, I had witnessed Chelva's deteriorating condition in a number of cultural functions he attended in Colombo, where saliva drooling from his mouth had to be wiped by a caring secretary who followed him attentively to prevent falls.

\section{Life threads relating to Chelvanayakam's Parkinsonism}

Parkinson disease is caused by the degeneration of dopaminergic neurons in the brain's substantia nigra. Both hereditary and environmental factors have been postulated as involved in the degeneration of forebrain dopamine systems [5, 6]. Consensus on the aetiology of idiopathic Parkinsonism points to insult by environmental neurotoxins in genetically vulnerable or susceptible individuals. Could it be that Chelva was a victim of an environmental insult? Some vital facts on Chelva's early life and family history do provide pointers to this line of conjecture.

Chelva was born on 31 March 1898, as the eldest child of James Visvanathan Velupillai and his wife Harriet Annamma in Ipoh, Malaya, where his parents had emigrated previously. I do not have information on when Chelva's parents emigrated to Ipoh. But Ipoh is located in the Kinta Valley, which was touted as the world's richest single tin field [7,8]. In 1884 the famous Kinta Valley tin rush brought an influx of immigrants from China and colonial India. The heyday of tin mining in Ipoh began in 1893. One could reasonably presume that Chelva's father was also one of these immigrants who landed there to make his fortune. He was originally a schoolteacher from Tholpuram, Jaffna. He left his teaching job in Jaffna and transformed into a 'contractor' [or businessman] in Ipoh.

This family background and the environmental conditions of Chelva's birth in 1898, strongly suggest that he or his mother, with Chelva in her womb, could have been victims of tin related toxic exposure. My hypothesis is strengthened also by the unfortunate fate of Chelva's two younger siblings, who died before reaching adulthood. Father Velupillai moved from Ipoh to Taiping after Chelva's birth. In 1901, a younger brother to Chelva was born. He was christened as Ernest Velupillai Ponnuthurai. He lived for 85 years in Jaffna [4]. In 1902, another younger brother named Edward Rajasundaram became the latest addition. He died at the age of 15 in 
Jaffna. One younger sister of Chelva, Atputham Isabel, had died as a toddler at the age of 2 years.

Chelva and his two siblings returned to Jaffna with their mother Harriet Annamma, when he was four, according to his biographer [4]. This could have been in 1902 or 1903. The suggested reasons for return of Velupillai's wife and two children to Jaffna from Malaya are twofold. First, was the delicate health of Mrs Velupillai in Taiping, where they had moved from Ipoh. The fact that she had lost a toddler would have weighed heavily on the minds of Velupillai couple. Second, was any good father's abiding wish to provide better education to his kids, and Mr. Velupillai had felt that colonial Jaffna offered better schools and a stimulating milieu of Tamil culture, in comparison to Taiping where they were living then. Chelva's father Velupillai remained in Malaya to earn and provide for his family. According to records, Chelva after completing his studies (and before entering the law school) visited his father once in Malaya in 1918, before the death of his father which occurred in 1919. One is not sure how old his father was when he died. He could well have been under 50 years. The toil in an emotionally sterile environment away from his family probably accelerated his death. Chelva's mother lived for 84 years and died on 16 March 1961 in Jaffna.

\section{Organotin toxicity}

Tin exists in the environment in multiple forms; as metallic tin, inorganic tin compounds, and organotin compounds. According to Krigman and Silverman [9], the daily intake of tin in human diet ranges from 0.2 to $17 \mathrm{mg}$, of which about 5\% is absorbed. Ingested tin is derived both from the food chain and food contamination. Biomedical literature published in the past 20 years [9$20]$ indicates that although toxicity of metallic tin and inorganic tin compounds is comparatively low, and occurs only in high doses and constant exposure, the toxicity of organotin, which can cause deleterious effects to the nervous system of invertebrates and vertebrates including humans, is of high relevance. The flow chart of neurological insult an individual receives, while living in a tin mining location as an infant, involves the following compounds. Cassiterite $\left(\mathrm{SnO}_{2}\right)$ is the main tin ore which is mined [18]. Other two tin ores are the complex sulphides, stannite $\left(\mathrm{Cu}_{2} \mathrm{FeSnS}_{4}\right)$ and teallite $\left(\mathrm{PbZnSnS}_{2}\right)$. Tin residues from the mining process, which leach into rivers and estuaries, are subjected to methylation by estuarine bacteria, which results in the formation of neurotoxic organotin compounds [20-22]. These organotin compounds undergo concentration along the aquatic food chain $[19,20]$ and ultimately reach the human targets via food, especially edible crustaceans, molluscs and nonmarine fishes. Gadd [23] has presented a comprehensive model on the biogeochemical cycling of organotins incorporating these steps. Among the organotin compounds, triethyltin is myelinotoxic and produces oedematous and vacuolar changes in the central myelin [9]. Experimental studies in rats and mice show that acute exposure to trimethyltin results in the alteration of dopaminergic and serotonergic functions in the brain [10-12]. Since Parkinson disease is caused by the degeneration of brain dopaminergic neurons, it can be argued that an accidental excess exposure of the brain to organotin compounds is a probable contributing factor for this neurodegenerative disorder.

Although Harriet Velupillai had a long life (exceeding that of her son Chelva), there remains the possibility that the environmental insult which contributed to Chelva's Parkinsonism resulted when he was a foetus. There is experimental evidence from Spain [24] for such an effect. Though it was Chelva's wish to "live to the same age as his mother Harriet Veluppillai - eighty four" [4], he fell short of this target by five years and died on 26 April 1977 after reaching 79 years, unconscious following a heavy fall. I do acknowledge that my hypothesis on the origin of Chelva's Parkinsonism suffers from the lack of supporting medical records pertaining to the period spent by him in Ipoh and Taiping, and the health status of Chelvanayakam's mother and two siblings who died before reaching adulthood.

\section{Conclusion}

From circumstantial (the childhood biographical) evidence, I conclude tentatively that Chelvanayakam's Parkinsonism could be attributed to organotin insults received while he was a foetus or an infant in the then tin rich Ipoh, Malaya.

\section{References}

1. Rajendran AM, ed. S.J.V. Chelvanayakam: A Tribute. Colombo, 1978.

2. de Silva GPSH. A Statistical Survey of Elections to the Legislatures of Sri Lanka 1911-1977. Colombo: Marga Institute, 1979.

3. Samarasinghe SWR de A, Samarasinghe V. Historical Dictionary of Sri Lanka. Lanham, MD: The Scarecrow Press Inc., 1998.

4. Jeyaratnam Wilson A. S.J.V. Chelvanayakam and the Crisis of Sri Lankan Tamil Nationalism, 1947-1977, London: Hurst \& Co, 1994.

5. Dunnett SB, Bjorklund A. Prospects for new restorative and neuroprotective treatments in Parkinson's disease. Nature 1999; 399: A32-A39.

6. Kruger R, Eberhardt O, Riess O, Schulz JB. Parkinson's disease: one biochemical pathway to fit all genes? Trends in Molecular Medicine 2002; 8: 236-40.

7. Choy KW. Tin distribution over granitic rocks in the Kinta Hills area, Perak, Peninsular Malaysia. Geological Society of Malaysia Bulletin 1977; 9: 233-52.

8. Rajah SS. The Kinta tinfield, Malaysia. Geological Society of Malaysia Bulletin 1979; 11: 111-36. 
9. Krigman MR, Silverman AP. General toxicology of tin and its organic compounds. Neurotoxicology 1984; 5: 129-39.

10. DeHaven DL, Walsh TJ, Mailman RB. Effects of trimethyltin on dopaminergic and serotonergic function in the central nervous system. Toxicology and Applied Pharmacology 1984; 75: 182-9.

11. DeHaven DL, Krigman MR, Mailman RB. Temporal changes in dopaminergic and serotonergic function caused by administration of trimethyltin to adult rats. Neurobehavioral Toxicology and Teratology 1986; 8: 475-9.

12. Ali SF, Slikker W Jr, Newport GD, Goad PT. Cholinergic and dopaminergic alterations in the mouse central nervous system following acute trimethyltin exposure. Acta Pharmacologica et Toxicologica (Copenhagen) 1986; 59: 179-88.

13. Change LW. The neurotoxicology and pathology of organomercury, organolead and organotin. Journal of Toxicological Sciences 1990; 15 (suppl. 4): 125-51.

14. McCann MJ, O'Callaghan JP, Martin PM, Bertram T, Streit WJ. Differential activation of microglia and astrocytes following trimethyl tin-induced neurodegeneration. Neuroscience 1996; 72: 273-81.

15. Fent K. Ecotoxicology of organotin compounds. Critical Reviews in Toxicology 1996; 26: 1-117.

16. Koczyk D. How does trimethyltin affect the brain? Facts and hypotheses. Acta Neurobiologiae Experimentalis (Warsaw) 1996; 56: 587-96.
17. Silva CR, Oliveria MB, Melo SF, Dantas FJ, de Mattos JC, et al. Biological effects of stannous chloride, a substance that can produce stimulation or depression of the central nervous system. Brain Research Bulletin 2002; 59: 213-6.

18. Westrum B, Thomassen Y. The Nordic Expert Group for Criteria Documentation of Health Risks from Chemicals and the Dutch Expert Committee on Occupational Standards. 130. Tin and inorganic tin compounds. Arbete och Halsa 2002; 10: 1-48.

19. Caussy D, Gochfeld M, Gurzau E, Neagu C, Ruedel H. Lessons from case studies of metals: investigating exposure, bioavailability and risk. Ecotoxicology and Environmental Safety 2003; 56: 45-51.

20. Rudel H. Case study: bioavailability of tin and tin compounds. Ecotoxicology and Environmental Safety 2003; 56: 180-9.

21. Ridley WP, Dizikes LJ, Wood JM. Biomethylation of toxic elements in the environment. Science 1977; 197: 329-32.

22. Hallas LE, Means JC, Cooney JJ. Methylation of tin by estuarine microorganisms. Science 1982; 215: 1505-7.

23. Gadd GM. Microbial interactions with tributyltin compounds: detoxification, accumulation, and environmental fate. The Science of the Total Environment 2000; 258: 119-27.

24. de la Fuente-Fernandez R. Maternal effect on Parkinson's disease. Annals of Neurology 2000; 48: 782-7.

Sachi Sri Kantha, Visiting Professor, Center for Human Evolutionary Modelling Research, Kyoto University-Primate Research Institute, Inuyama City, Aichi 484-8506, Japan. Tel: +81 56863 0595, e-mail: kantha@pri.kyoto-u.ac.jp (Competing interests: none declared). 